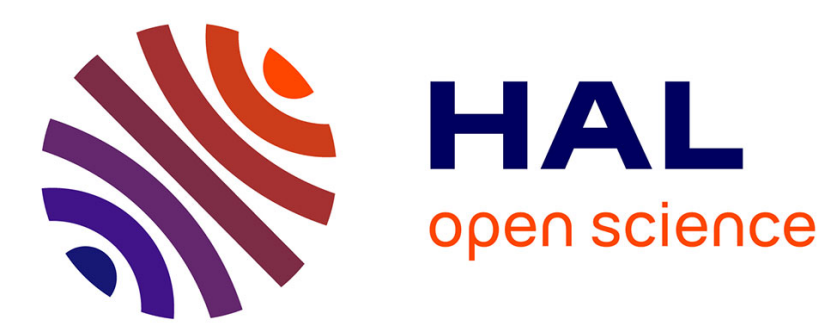

\title{
Strategic Representations, Territory and Borderareas: latin america and global disorder
}

Edgardo Manero

\section{To cite this version:}

Edgardo Manero. Strategic Representations, Territory and Borderareas: latin america and global disorder. Geopolitics, 2007, Vol 12 (1, january-march), pp.19-56. halshs-00233006

\section{HAL Id: halshs-00233006 \\ https://shs.hal.science/halshs-00233006}

Submitted on 4 Feb 2008

HAL is a multi-disciplinary open access archive for the deposit and dissemination of scientific research documents, whether they are published or not. The documents may come from teaching and research institutions in France or abroad, or from public or private research centers.
L'archive ouverte pluridisciplinaire HAL, est destinée au dépôt et à la diffusion de documents scientifiques de niveau recherche, publiés ou non, émanant des établissements d'enseignement et de recherche français ou étrangers, des laboratoires publics ou privés. 
Version préliminaire de l'article publié dans Geopolitics, VOLUME 12, ISSUE 1, 2007, pp :19-56. Copyright (C) Taylor \& Francis Group, LLC

ISSN: 1465-0045 print / 1557-3028 online

DOI: 10.1080/14650040601031123

\section{STRATEGIC REPRESENTATIONS, TERRITORY AND BORDER AREAS: LATIN AMERICA AND GLOBAL DISORDER}

\section{EDGARDO A. MANERO}

Centre National de la Recherche Scientifique (CNRS)/Toulouse II, France

In Latin America, post-Cold War ideas about defence and security broke down geopolitical logics that had been historically accepted by Latin American armed forces. These ideas also provoked a partial downfall of one component of their traditional strategic representations: This geopolitical determinism explained post-colonial conflicts as being due to historical influences and to disputes about power and territory. Paradoxically, national frontiers are emerging and are threatened by destabilisation. The new conception of the border and its revalorisation at the strategic level must be related not only to the character of postCold War threats but also to the new security vision prevailing in the international system. This vision cannot be separated from US strategic representations, which emphasise the "global" character of risks and security mechanisms. Thus, it appears that the transnational dimension of the strategic representations promoted by the United States does not correspond to the traditional concept of national territory. This concept, which is the basis of the reshuffling of military architecture in Latin America after the Cold War, is rooted in a representation of the region that has been present since the 1940s but was systematised under the Democratic Clinton Administration in the 1990s and further developed under the presidency of Republican George W. Bush in the early twenty-first century.

\section{INTRODUCTION}

The aim of this paper is to examine and hightlight the critical issues of security and the defence of frontier areas in Latin America. In such places, the traditional paradigm of sovereignty comes into conflict with a new paradigm, one still in gestation, which is centred on the political and strategic representations (1) of the United States that aim to dilute national sovereignty in favour of global interests. In effect, the conflict seems to express the discrepancy between a global economy and a system of security, particularly on the periphery, that is still based on territorial defence.

Paradoxically, in a context in which globalisation as a process and as an ideology challenges the idea of borders, national frontiers are emerging and are threatened by destabilisation.(2) Territorial and boundary disputes still exist and some have appeared for the first time. 
The importance of frontiers at a strategic level must be examined in light of the new security and defence questions that have been identified by Latin American armies. These questions relate to the evolution of menacing entities and to the United States' intention of exporting its own strategic representations.

In the 1990s, Latin America witnessed the birth of a strategic model, which has expanded since September 2001, whereby the United States promotes, at a global level, a security system that is centred on the transnational violent regulation of spaces. (3) Meant to manage an international denationalized system, this model is based on paramilitarised local vigilance, domination and repressive devices, all of which are intended to preclude all questions concerning the possible enlargement of liberal democracy and a market economy.

The model takes its form from norms and rules that tend to limit sovereignty through global decision-making processes whose objectives are to guarantee the security of a global economy and its means. It not only aims to disaggregate, in the name of political and economic freedom, any principle of national territorial sovereignty in favour of a universalisation of the enjeux of security but is also compatible with the state-centred answer to the events of 11 September 2001, as well as with the new global mission known as the struggle against terrorism.

This new regulation has led to a review of the notions of national security and frontier. Next will come a reconsideration of internal-external relations, the links between civil and military spheres, the control of legal and illegal transnational networks, aspects of enemies and threats and notions of territory and sovereignty.

The modifications that have come out of this model have deeply affected the idea of both national territory (sovereignty's traditional symbol) and security institutions. They have also meant the end of old representations of the frontier as a limit to the management of sovereign power. Indeed, this model has introduced a major problem for institutions such as armed forces, for which defence of sovereignty has been the main justification for their existence.

Globalisation has caused a major crisis for Latin American armies because their existence is so closely bound to traditional conceptions of the national state, territories and security. Except for Colombia, and its policy of "democratic security", and Venezuela, with its post-modern version of "people in arms", there is not, in post-Cold War Latin America, a strategic program comparable to what existed during the Cold War, either in civil society, in military institutions or in the political community.

Increases and changes in threats raise questions about traditional forms of intervention, military planning and, in particular, representations of the enemy. Identification of threats to the state or to ideology seems to be in a state of ongoing crisis, despite the comeback of states exporting ideology tinged with revolutionary messianism, such as that of Hugo Chavez in Venezuela. This strategic vacuum has been filled by various options that are poles apart, such as participation in international missions, political commitments to rebuilding the idea of "nation" and "state" or the use of the army for police tasks in the domain of domestic security. (4) The post-Cold War period maximises Latin American strategic heterogeneity. (5)

Studying strategic representations and practices (6) enables a consideration of sovereignty and territory in settings in which frontiers - which functioned during the 19th and 20th centuries as isolated compartments of social conflict that allowed the organisation of 
a monopoly of legitimate violence - are going through a paradoxical process. Even as they become a strategic priority, they are widely questioned.

Such an undertaking also explains the isomorphism and some of the characteristics of Latin American armed forces. In addition, it makes it possible to analyse changing tendencies concerning the management of violence and to propose a prospective vision of possible evolutions, not only in armed and security forces but also in the policies of the United States in Latin America in relation to changes on a worldwide scale. Furthermore, it allows an understanding of the problem of the influence of strategic cultures (7) in the design of security as the ideological and social values that underlie the violent management of Latin America's chronic instability.

Whether we are talking about tangible demonstrations or about representations, such deep changes are at stake in Latin America that it is necessary to emphasise the tipping points and the breakdowns more than the continuities, although we should be careful not to underestimate these.

\section{THE IMPORTANCE OF TERRITORY IN THE NATURE OF THREATS}

At several levels, differences exist not only between countries and regions but also between security institutions; in Latin America, post-Cold War ideas about defence and security broke down geopolitical logics that had been historically accepted by Latin American armed forces. These ideas also provoked a partial downfall of one component of their traditional strategic representations: This geopolitical determinism explained post-colonial conflicts as being due to historical influences and to disputes about power and territory.

Even when a conflict expresses a traditional subregional polarity in the form of a confrontation between states, as in the case of Uribe's Colombia and Chavez's Venezuela, it is more in relation to the problems of the post-Cold War period than a logic of territory established on historical relationships between power and space or territorial distribution. This does not imply, however, the negation of the inertial dimension of regional competition or the weight of the territory in the imaginaire collectif.

In Latin America, since the formation of post-colonial states, "neighbourhood Geography" has strongly influenced decision making. Territorial conflicts were the most visible forms of contesting state sovereignties. Currently, in many countries, struggles for influence over territories are developing regardless of ideologies and are reappearing in different situations. However, and it is a Latin American paradox, if conflicts between states over boundaries are relatively frequent, wars between states are relatively (8) rare.

Thus, we are facing a new vision of relationships linking territory and security, a vision that shocks traditional strategic representations based on territorial proximity and affects the more general idea of "border areas as limits to be defended".(9)

The three geo-strategical logics of conflict - fluvial, maritime and territorial - that established representations of territorial proximity have been dislocated. Changes are shown through a decrease in the orthodox adherence to the "realist theory" (10) of international relations and to geopolitical concepts that characterised an important part of Latin American military thought. In the post-bipolar world, strategic representations have developed in which neither ideological conflict nor regional war is at the centre of military-planning concerns. 
The main changes are the end of the presence of external "historic" adversaries and the alteration of the nature of enemies, meaning that threats no longer are associated with a state.

Although the lack of homogenous strategy is still a characteristic of Latin America, a few problems with common strategic value can be underlined. This does not imply considering the army as a uniform entity: Differences exist between different armies and inside the institution itself.

Latin American armies developed from people's militias that formed during the wars of independence. This particular history, which is linked to the idea of liberation and emancipation, gave armies a long-standing legitimacy. In Latin America, the fight for independence, civil wars and the conquest of territories modelled the nation in its most literal sense, armies having had a central role in the definition of state limits and the establishment of collective identity. In the nineteenth century, regular armies had two important functions: 1) to be used as a factor of national unity, reinforcing official centralisation with the elimination of provincial caudillos; and 2) to incorporate territories through exploration and conquest, sometimes resulting in the elimination of native populations. A third function, inherited from the old colonial order, was to guarantee the balance of power with neighbouring states.

However, another function was added to these traditional functions (defending national borders and guaranteeing political sovereignty): that of preserving internal order. Based on political, social and geographical instability, armies became the guardian of the social order, the protector of borders and the promoter of collective identity. During the Cold War, Latin American armed forces thought and acted in terms of power interest, according to the ideas of H. Morgenthau. (11) With some slight differences, they almost all shared traditional "Realist Theory" principles: a pessimistic vision of human nature, the idea of the state as an autonomous unitary actor, anarchy as the organising principle in international relations, subordination of moral to national interest, perception of war as an endemic element of politics, primacy of the state and national identity conceived as universal in time and space, war as a trans-historic phenomenon and the need for armed forces to face the traditional dilemma of security.

Within the framework of the realist paradigm, the balance of power notion structures foreign-policy construction. By hoping to act in the national interest, armies have thought of politics as a "zero sum game". Any action by one state was perceived as detrimental to another. For Latin American armies, what was really at stake in state relationships was power and rivalry. Balance of power sustained peace in South America from the second half of the 19th century on, and the consolidation of this system is one explanation for the low incidence of warfare among South American states.

The issue of territory must be considered within the framework of geopolitical thought that developed as a "science", which would establish appropriate laws of the space for judging the rights of states to specific territories. Throughout the twentieth century, geopolitical intentions were an essential element in the strategic representations of Latin American armies, mainly in Brazil, Chile and Argentina.

Latin American geopolitics is the direct heir to this ideology of conquest, which was born at the end of the nineteenth century and created important stereotypes that spread to political communities. This ideology emerged at the same time as European 
imperial expansion and the rise of science and modern industry, and geopoliticians could be found in Latin American military academies who were convinced by the scientific reasoning of German geopoliticians. (12) It is not surprising, therefore, that in this area, geopolitics continued to be used during the second half of the twentieth century as it was at the beginning of the century.(13) By contrast the post-Cold War period has seen the weakening of the effects of traditional forms of geopolitical conceptions.

On the other hand, the importance given to territory by the armed forces cannot be separated from Clausewitz's (14) ideas considering territory as an essential factor of war, together with population. Latin American armed forces defined the concept of territorial defence centred on a very narrow idea of general interest. This representation of territorial sovereignty led to an absolute "sanctuarisation" of the defended object. This logic would be driven to its paroxysm by the Argentinian and Brazilian nuclear programmes, which represented attempts to sanctuarise their territories through nuclear deterrence.

Directly inherited from Spanish-Lusitanian conflicts in the La Plata region, relations between Argentina and Brazil were based on mutual mistrust and competition to establish hegemony in the Southern Cone. Their rivalry took the shape of a low-intensity war of prestige, during which true conflict never seemed to be a credible proposition. The real territorial conflicts could not be compared with those of other regions. Thus, unlike other hegemonic arguments, Argentinian-Brazilian rivalry did not imply a constant risk of war between the different states of the region; rather, there was a shared determination of both countries to consider the region as a secondary strategic place. In Latin America, "hereditary enemies" never developed hostility based on ethnic, religious or cultural criteria. Rivalry was the result of traditional conflict between nation-states inherent to a particular conception of the search for regional hegemony. It was about normal rivalry between regional powers and a result of "neighbourhood logic". Thus, Argentinian-Brazilian rivalry was closer to the Franco-German conflicts of the nineteenth and first half of the twentieth century than to the Indo-Pakistani conflict. (15)

These rivalries and their consequences - paranoiac attitudes and sentimental overloads - have justified arms races between South American countries. However, arms races, impossible to divide of corporatist interest, have never had the importance of other zones. These races, even the nuclear ones, did not constitute a serious threat to safety and regional stability.

This perception of the nature of threats did not disappear with the rise, during the second half of the twentieth century, of the other component of traditional strategic representation: the "ideological threat" and its corollary, the "enemy within". Throughout the Cold War, subregional polarities (Argentina-Brazil, Argentina-Chile, Chile-Bolivia, ChilePeru, Peru-Ecuador, Venezuela-Colombia) accompanied internal war and social-control practices.

The geopolitical and strategic representations of the Latin American nations are, essentially, terrestrial. Land oriented, this representation is a result of the adaptation of the European paradigm of strategic interaction with the neighbouring state. However, Latin America has developed a heterodoxical conception of national neighbourhood, in which the "neighbourhood logic" is modified by the ideological dimension of the impact of threats and by the presence of foreign forces. Since colonial times, the Latin American evolution of territory has been deeply affected by worldwide incidents. 
Since the second half of the twentieth century, US security and defence policies have had a strong influence on the Latin American conception of regional security. The presence of the United States in the hemisphere has meant an important transformation of the European paradigm of strategic interaction between neighbouring states as a result of the post-colonial order.

The United States was decisive in constituting the "ideological threat", as expressed in the Doctrines of National Security (DSN) and its consequence, "ideological borders". Since the 1940s, through its hegemony, the continental dimension of security action has developed in the name of defence of the West, expressed in three institutions: OAS (Organization of American States), JID (Inter-American Defense Council) and TIAR (Inter-American Treaty of Reciprocal Assistance). Since the 1950s, the United States has made permanent appeals to the hemisphere to support the fight againt "communism".

A certain form of "Bolivarism" was at the basis of the call by the United States for the fight against communism and "subversion". During the Cold War, the multiplication of military advisers, permanent contacts between armies, joint exercises, and the training of local armies all hightlight not only the importance of the United States in the security policies of the subcontinent but also its continental dimension. The Inter-American Defense Board, training courses with the Inter-American Defense College and biannual conferences of American armies established a tradition of dialogue and collaboration between the armed forces.

The agreements that, during the Cold War, instituted the bases of the regional security system that underlines the objectives and consequences of the reinforcement of the interAmerican system of security aimed to integrate Latin American armies in the US strategic device, starting from the definition of the communist threat. This has had consequences on the strategic cultures of Latin American militaries.

The strategic culture of Latin American elites took form in the nineteenth century with the formation of the post-colonial state. The emergence of the USSR and even more so the continuation of the Second World War, as well as the appearance of several populist protest movements, introduced major changes into this culture. The increase in the exogenic influences on the development of the strategic representations of the armed forces is the most important demonstration of that. For the whole of Latin America, the United States has had a central role in the formulation of security policies since the second half of the twentieth century. The influence of the French military also should be considered, especially at the operational level and very particularly in the Argentinian case. Nevertheless, the postcolonial past (nineteenth century to the beginning of the twentieth century) is a present past and thus operational in Latin America.

Since the 1950s, Latin American armies have detected and identified threats according to transnational strategic representations. Indeed, they have developed a vision of security closely related to the hegemonic representations within the international system, the result of which was the passage of the DSN. Thus, under the command of Onganía in the 1960s, the Argentinian army favoured an alliance with the Brazilian army, whose objective was to form the core of an inter-American force to fight against subversion. In the 1970s, the "Condor Plan" (16) fell under this logic. 
This change corresponds, on one hand, with a new international situation characterised by the entry of Latin America into the Cold War with the Cuban question (1959) and with the redefinition of the threats established by the United States. On the other hand, it corresponds with national situations characterised by the autonomy of the army compared to the civil capacity and by the emergence of new politico-social actors like the populists. In the Argentinian case, emphasis must be placed on the role of the passage of the Doctrines of National Defense, which centred on the territorial threat within the DNS, which, in turn, centred on the ideological threat in the attempt to counter the effects of Peronism in the society and the army after the 1955 coup d'état. (17)

However, the competition of "neighbourhood logic" is a fact that could not be eliminated, either by the continentalisation of the armed forces or by the influence of the United States, via the DNS. US hegemony has been irrelevant in explaining the prospects of war and peace between states in Latin America and the United States has played a limited role as an intermediary. (18) Although US occupation of Nicaragua in the early twentieth century may have temporarily stopped wars in Central America, it did not settle the underlying conflicts. (19) The second half of the century witnessed important conflicts related to territories: Honduras-El Salvador (1969), Argentina-Chile (1978), Guatemala-Belize (1981), Argentina-United Kingdom (1982) and Peru-Ecuador (1995).

The will of the area's authoritarian regimes to establish military alliances to fight against international communism and communist representations of the international system did not prevent traditional rivalries. Domination and mistrust were at the centre of these strategic representations, since the principal regional actors, under this logic, conceived of themselvesas being beyond ideological and cultural cleavages.

The similar perception of the domestic and international order held by the military regimes of the 1970 s, however, did not hide a mutual suspicion at either the bilateral or the subregional level. Despite moments of ideological understanding between these military governments, mistrust toward their neighbouring states continued, and even increased. The conflict between Videla's Argentina and Pinochet's Chile in 1978 illustrates this. Their joint action internationally did not preclude them from being wary of neighbouring states' armies and did not make it possible for them to avoid conflict at the regional level.

In Latin America, any strategic analysis must consider the contradictions between the fact that under US influence the dynamics of security in the Southern Cone have been largely regionalised since the Second World War and the fact that the regional balance of power and the fight for hegemony constituted a priority for certain countries of the area, particularly between Brazil and Argentina from the 1940s until the 1980s.

\section{A MAJOR STRATEGIC MODIFICATION}

A period of strategic uncertainty has begun due to the loss of the traditional image, or perception, of the enemy. In the post-Cold War period, debates on security issues focus on the new concept of safeguarding interests, which can no longer be conceived as the "traditional" defence of a country's borders or territory. It has entailed a major modification in the conception of sovereignty that had characterised the region. This new representation of the world is gradually imposing itself and changing the traditional attachment to the protection of territory in its traditional form. Traditional military threats (territorial aggressions and dominations, power rivalries, proliferation of biological, chemical and 
nuclear weapons) are either not included in military statements or subordinated to new strategic concerns.

Concern about increased military capacities has been focused on Chile only since the mid-1990s. Bolivia and Peru have repeatedly accused Chile of promoting an arms race, a consequence of the end of the US ban on arms sales in Latin America, known as the Humphrey-Kennedy Act. At the beginning of the twentieth century, the concern also focuses on Venezuela, although the portion of GDP dedicated to military expenditures remains low in this country. Arguing that they are renewing obsolete military equipment, Chile and Venezuela have become the main arms buyers in Latin America. However, the type of arms bought in each case illustrates a deep strategic rift between the two nations. While Chile has opted for the most technologically advanced weapons, Venezuela has acquired material that it will use mainly to arm a significant proportion of its own population. The United States has expressed concern about Venezuela buying its arms from Russia - mostly Kalashnikov assault rifles - because it suspects that Chavez is channelling the guns to Colombian guerrillas. The United States and Colombia have both shown concern over the purchase of weapons by the Chavez Administration. (20)

However, Latin American armies have not built a new threat as important

as that of communism. For the states that make up the post-Cold War inter-American system, the principal threats to the democratic governments are drug-trafficking and organized-crime activities, terrorism and political and social instability. (21)

Clearly, the problem of the alteration of the security system is settled. The OAS General Assembly in Santiago de Chile (June 1991), after considering the issue of hemispheric security co-operation, continued with declarations of defending democracy, mechanisms of collective security and arms control and limitation of weapons of mass destruction (22); this assembly set up the foundation for the construction of a co-operative security system. In October 1991, at the Inter-American Defense College in Washington, DC, the chief of staff of the Argentinian navy, J. Ferrer, in the context of a strong connection between the Argentinian and US governments, maintained that the old theory of strategic planning based on a war with a determined enemy had become unrealistic and that a military capacity without determinism, or pre-established enemies, was needed. During the nineteenth American Army Conference in Washington, DC (November 1991), the General Secretary declared that as far as Latin American armies were concerned, the challenges were political violence, drug trafficking and the economic and social conditions of the region. He hardly mentioned the traditional missions of armies. (23)

The modification of the collective security system conceived during the Cold War was a central question in the Pan-American strategic debate of the 1990s. This system, of which the Inter-American Treaty of Reciprocal Assistance (TIAR) was the most obvious expression, was designed to address extra-continental, traditional threats coming from a state having a territorial character.

In South American states during the 1990s, the tendency to think in terms of traditional military power to protect territory lost momentum. This resulted not only in the traditional conflict hypothesis becoming out-of-date but also in the beginning of a predisposition to co-operation on military questions. A growing confidence in the regional security scheme had led to the disappearance of the traditional fear of the threatening neighbouring state. This transformation of the state's relationship to territory and region is highly significant. Since the 1980s, a new model of development, economic liberalisation and regional integration has significantly modified territories in Latin America. 
MERCOSUR (Southern Common Market) has changed relationships and transformed the nature of conflicts. The construction of an interstate peace zone is a major strategic fact. Integration has deeply affected the old logic of the threatening state. This transformation in strategic representations must be understood in relation to the construction of a South American peace area among states. To do so, it is necessary to consider the process of democratisation and the recovery of civilian control over the military, especially regarding defence policy, which was historically denied to civilians.

In the early 1990s, conflict perceptions were informed by geo-economics. Rivalries of an economic order in particular appeared in the economic and communication policies of MERCOSUR. Thus, Brazil's will to drive the economic flows of MERCOSUR through the economic pole formed by Rio Grande do Sul and Santa Catarina (especially Porto Alegre harbour) appears like an update of geopolitical principles. In the 1930s, Mr. Travasos, an important Brazilian geopolitics specialist, supported the idea of ending the natural attraction that the Rio de la Plata exerted on the Mediterranean countries. He explained that Brazil should do so by attracting Bolivia and Paraguay to the Brazilian harbours. The SantosCorumbá-Santa Cruz de la Sierra railroad is the result of this strategic thought.

The nature of national armies and security forces, the threats and the regional security system were all redefined by the MERCOSUR integration process. Since the end of the Cold War, security dynamics have been considerably regionalised. (24) However, despite the weakening of this geopolitical determinism (which explains conflicts by the influence of history and by rivalries over power and territory), security is still fundamentally conceived according to a national view. Latin American military institutions are aware that the postCold War era is a historical break from the past. The consequence of this change is the search for a new strategic doctrine to fill the void left by the DSN. However, in accordance with the realist tradition, the state is still considered the fundamental actor in international relations. Latin American military institutions continue to follow the Hegelian idea that the highest duty of the state is its own preservation. (25)

These strategic alterations have been inserted into the international system, despite the tendency, observed since the Cold War, of territory, in its traditional form, to lose importance in conflicts between states. (26) The concept of territory underwent important modifications with the transformation of the historical relationship between power and space. (27) Currently, the territorial reference to sovereignty is minor. The representation of space is freed from the physical borders suitable for traditional geopolitics, and the concept of territory has widened because of technological transformations and human behaviour. Paradoxically, this reduction of the strategic relevance of territory does not imply the same for borders. The Latin American border areas remain a zone of geopolitical friction and tension. Thus, the recovery of the strategic importance of the borders came with the end of the Cold War.

By the end of twentieth century, the most serious boundary disputes in South America, the result of colonial legacies (Argentina and Chile; Ecuador and Peru), were definitively settled. Only four territorial, non-maritime, classical disputes still remain active today. Three are decolonisation issues that are consequences of British colonial policies after Latin American independence: between Argentina and the United Kingdom, between Venezuela and Guyana and between Guatemala and Belize. The other is an irredentist issue mixed with the problems related to neo-liberalism: Bolivia's search for an outlet to the Pacific Ocean. 
However, at the same time, the post-Cold War era saw the re-emergence of a series of disputes and the emergence of new controversies in the Caribbean and the Andes. (28)

In Latin America at the beginning of the twenty-first century, the resurgence of sovereignty conflicts cannot be explained simply by the residual weight of territory in collective representations or because states still have not dealt with their colonial legacy. The resurgence of conflicts must be explained in relation to the crucial question of the control of "flows" and "stocks", whether legal (oil, gas, water, minerals) or illegal (drugs, smuggling, migrants, etc.).

Thus, the conflicts in the Caribbean region must be examined in light of the controversies and rivalries involving resources, whether "real" or "imagined". These are the result of a 1982 revision in the international maritime law (United Nations Convention on the Law of the Seas) that extended maritime jurisdiction and the development of new technologies to exploit marine and seabed resources. The appearance of the autonomist movement in the Zulia region of Venezuela or in the Bolivian Oriente must be studied as part of the debate about the appropriation and use of the profits derived from oil and gas.

Bolivia has become the paradigm not only of the relationship between conflict and sovereignty on resources but also of the return of secessionism, irredentism and annexationism. However, the Oriente region's appeal for autonomy carries much more weight than the claim by a minority of Oriente dwellers to become part of Brazil or Argentinian fundamentalists' nationalist claims for the Tarija province or the claim by a minority of Peruvians for the Pando province. In Bolivia, events that have occurred since April 2000 have renewed tensions between integration and division, but the danger of fragmentation cannot be blamed on grass-roots movements but rather on the elites of the Bolivian "Oriente", who seek to benefit from the economic possibilities of gas.

In fact, opposition to liquefied petroleum gas exports from Bolivia to the United States through a Chilean harbour was a central element in the popular upheaval that led to the resignation of President Sánchez de Lozada in 2003. This problem has since resurfaced on the diplomatic agenda and brought back a fundamental issue of South American geopolitics: Bolivia's sea access. But, far from the traditional territorial claim, this question is based on a sovereignty demand for the control of the exploitation of nonrenewable natural resources.

The reference to Chile should be understood in the context of the most traditional residual character of nationalism. The Bolivians' anti-Chilean feeling can be better appreciated in light of the rumours about the utilisation of Chilean mercenaries for civil murders by the government of Sánchez de Lozada. However, the present conflict must be understood not only through the collective memory of the Pacific War and the loss of territory in 1883 but also in the context of the resistance to the depredation of national resources, which are exploited by transnational firms. This struggle is part of a conception of sovereignty that runs deeper than that based on territorial claims. The purpose of the popular uprising was to prevent gas from taking the same route as silver, nitrate and tin. It is not a question of principles against natural resource exports, but rather a refusal of the detrimental conditions of natural resource negotiations that have damaged the Bolivian state and its citizens. The importance of the Bolivian movement lies in the fact that the marginal sectors of its society, and some sectors of the armed forces, have become fully aware of the need to recover their expropriated natural resources. 
It does not seem likely that a context of spilled-over conflicts between states will lead to a regional war, yet the fear of this occurring is still felt in the region. Since the 1990s, Colombia has been the most obvious example of this. In the context of "Plan Colombia", the bordering countries have shown their preoccupation with the permeability of borders. The border is a central component of a conflict that is defined by the increased autonomy of nonstate actors compared to their heterogeneity, the control of illegal "flows" and "stocks" and a high degree of intervention by the hegemonic power, the United States.

The concern of the governments of the countries bordering Colombia has increased due to the expansion of the armed struggle, in particular, toward the Amazon basin. Brazil, Peru and Venezuela have indicated that the military component of "Plan Colombia" will affect the whole Amazon region, specifically, in terms of expulsion toward their borders of narcos and guerrillas, migrant populations, actions of paramilitary organisations, expansion of illicit crops, pollution, and so forth.

At the beginning of the twenty-first century, a retrospective view illustrates the dimension that borders have taken in Colombia's relationship with its neighbouring states. The constant incursions of the Colombian military into Ecuadorian territory to pursue guerrillas have caused a deteriorating relationship between the two countries. Panama also has increased the deployment of its security forces (it has no military institution) along its border with Colombia. To the activities of the FARC - Front 57 - and the paramilitaries must be added two other issues: organised crime (kidnapping and drugs, illegal migrants and arms trafficking) and a humanitarian problem with Colombian refugees in the Darién region. The Panamanian government and the United States perceive both these issues as threats.

Brazil has beefed up security on its border with Colombia, a priority of the United States, by launching the Calha Norte plan in order to prevent border crossings by guerrillas and drug traffickers. The Brazilian military is engaged in the fight against organised crime and increasingly views the drug trade as a national security issue. However, the Brazilian Minister of Defence, J. Viegas Filho, has said that the government will not modify the constitution to accommodate US policy. (29)

Venezuela is of particular importance in this scenario. Colombia, the main ally of the United States in the area, plays a central role in the US policy of containing the "Bolivarian Republic". In March 2006, US President George W. Bush proposed that US aid should be used against all "threats to Colombian national security".(30) The murder of Venezuelan soldiers (which Colombia has blamed on guerrillas and Venezuela on the paramilitary) and the capture of the FARC leader R. Granda are directly related to the question of sovereignty and the permeability of borders. Venezuelan President Hugo Chavez has accused the Colombian government of violating his nation's territorial sovereignty with American support. The Colombian military and the Uribe government have accused Venezuela of not fighting international terrorism. Chavez, however, considers the FARC neither a threat to his government nor a terrorist organisation.

In the post-Cold War period, traditional conflict hypotheses that are bound to the territorial ambitions of a country, for example, expansionism, are depreciated. Therefore, the threat to territory no longer appears to be the result of national power and the military struggling for territorial possession, but rather the consequence of either weakened sovereign control, the deficit of the capacity of imperium or the loss of the national monopoly on 
violence in border regions, which enables the development of menacing entities (criminal organisations, subversive movements) and interventionist policies.

Thus, post-Cold War conflict in relation to territory is not borne by the power of the states but by their weakness or their so-called weakness. Latin American states have been profoundly transformed, debilitated by neo-liberalism's ideological framework. The modification of the nation-state concept disposing of frontier under an absolute control is one characteristic of the global world. (31) At the periphery, the state has difficulty mastering the decisive flows of the global economy (information, capital, population). (32)

The principle of the intangibility of borders remains strong, the respect of political sovereignty is universal and the refusal of territorial invasion is unanimous; thus, in the global disorder, borders are profoundly affected. National borders will be more permeable than in the past. (33) Although the internal sovereignty principle is put into perspective by globalisation, the state continues to have both authority and legitimacy at the international level: States have armed forces, conduct diplomacy, negotiate agreements, make war, control international organisations and influence production and business.

The absence, real or presumed, of effective sovereignty allows the development of a dangerous entity as it permits the intromission of hegemony. The new conception of the border and its revalorisation at the strategic level must be related not only to the character of post-Cold War threats but also to the new security vision prevailing in the international system. This vision cannot be separated from US strategic representations, which emphasise the global character of risks and security mechanisms. They confirm that the defence of sovereignty will no longer be limited to the protection of borders and territory. Armies must have a regional view on the protection of each country and work together to defend sovereignty with a regional conscience and an international solidarity.

As far as the United States is concerned, transnational threats respect neither geographical nor moral boundaries and are common and require collective action. In March 2003, the chief of the US Southern Command said that the threat to countries in the region does not come from the military force of an adjacent neighbour or from a foreign invading power. Rather, "today's foe is the terrorist, the narco-trafficker, the arms trafficker, the document forger, the international crime boss, and the money launderer". (34) In 2005, General Craddock of the US Southern Command stressed the strategic priorities of the United States in the region: the construction of a co-operative security community, populism as a threat to Latin American states, the existence of Islamic radical groups that take part in illegal activities, support for the Colombian government in its fight against armed groups and the influence of China in the Americas. (35) In a 2006 meeting of Latin American armies in Montevideo, General Craddock supported the view that although the world had changed and "new threats" exist today, the regions' armies were structured according to the conflicts of the last century. (36)

In the post-Cold War period, the security and defence policy goals for the region promoted by the United States are closely related to transnational concepts that tend to subordinate national sovereignties to global interests. This idea is based on a group of founding principles for "global civilisation" that were inspired by Anglo-Saxon representations that do not match the precepts of Latin American regional political culture. 


\section{THE GEO-STRATEGIC VISION OF THE REGIONAL CONTINUUM}

Latin America, post-Cold War, appears to be of marginal strategic concern to the United States because there is seen to be little risk of the region becoming involved in global tensions. In comparative terms, the area has very low levels of military expenditures. Nevertheless, although the priorities of the Bush Administration suggest the opposite, Latin America is a key space in the geo-strategic expansion according to US norms and interests.

The region has always been considered of interest by the United States and, since the Cold War, has become a source of energy flows for the United States, Europe and Asia, a significant market and a troubled territory (slightly legitimised powers, drug production and other trafficking, permanent political and social uprisings). The region has had access to the usual stabilisation and integration instruments (private investment, regional collaboration and bilateral co-operation), while US policy for Latin America has been based on the revitalisation of the OAS and the diplomacy of hemispherical summits.

The US strategy for Latin America is based on its geo-strategic view of a regional continuum that can be incorporated into globalisation by the "enlargement" carried on by the Clinton Administration in the 1990s. The policy of 'enlargement' is significantly different from the Cold War policy of 'containment', which it replaced; the goal of this new policy is sustained expansion of the market economy and representative democracy, as opposed to a planned economy. (37) The two projects that express US policy in Latin America - the Free Trade Area of the Americas (FTAA) and the Cooperative Hemispherical Security - were developed during the Clinton Administration at the first Hemispherical Summit of the Americas in Miami (December 1994) and at the first Meeting of Ministers of Defense of the Continent in Williamsburg, Virginia (July 1995).

However, this regionalising of globalisation, for example, the FTAA and NAFTA (North American Free Trade Agreement), does not take into account the difference between developed and underdeveloped countries and it fractures the notion of North-South geography. In this context, geographical continuity does not have any importance at all, a point of view that comes from the Anglo-Saxon tradition of spreading one model of production and consumption throughout the world. An example of this might be the Chilean demand for participation in NAFTA.

Since World War II, the United States has attempted to spread its production and mass-consumption model if not to the whole world, at least to its main partners, (38) by trying to create an extended open market, while developing a network of free-trade agreements. To meet this objective, a number of actions must be taken, including economic reform, breaking down trade barriers, liberalisation of trade and investment flows, elimination of public industrial policies and the creation of a vast free-trade market by private sectors.

After the Miami Summit of 1994, the Clinton Administration supported the FTAA, an idea developed by the previous Bush Administration under the name of "Initiative for the Americas" that was based on trade liberalisation and investment growth toward a free-trade zone. This idea has been supported by the present Bush Administration; in 2005, at the Mar del Plata Summit, administration officials revived the subject, despite resistance from MERCOSUR and Venezuela. In addition, during 2004-2005, the original version of the FTAA was sternly refused by Argentina, Brazil and Venezuela and had to be modified in order to obtain an agreement. The failure of the FTAA led to bilateral free-trade negotiations between the United States and countries such as Colombia, Peru and Ecuador. 
As strategic projects, both NAFTA and the FTAA are heirs of the Monroe Doctrine. Geopolitically, the FTAA conforms to the US tradition that aims to prevent other great powers, such as the EU or China, from interfering in Latin America.39 Clearly, the United States has resolved to secure an enclosed area of influence in order to limit interaction with extra-regional firms and countries. By resisting economic penetration in the region, it seeks to exclude peer competitors. The FTAA is a way to increase its commercial presence and reconstitute a captive market by widening investments. This happened during the 1990s, when European capital had a significant presence in Latin American privatised firms.

The second aim of the US tradition encompassed by the FTTA is to prevent the formation of a South American counter-hegemonic block. This means avoiding the creation or consolidation of a relatively autonomous area and subsuming regional economic-integration initiatives (MERCOSUR, the Andean Community of Nations) or concerted political planning (Rio Group) in which the United States does not participate directly. In this context, MERCOSUR's disintegration under NAFTA is essential. Until the Summit of the Americas, MERCOSUR had occupied an irrelevant place on the US list of priorities because Washington was focused on other problems in other regions. For this reason, MERCOSUR could be consolidated without external pressure.

Constructing a free-trade hemispheric zone means more to the United States than just eliminating internal customs tariffs that still protect large productive sectors in Latin America. The institutional advance toward the continent's economic integration is not enough. State intervention in the economy and in the national borders appears as a limit to economic development. The exploitation of resources is carried out by private actors that can no longer be limited by territorial or political pressures. The breakdown of trade barriers must be followed by a physical intercommunication between the countries of America. This physical interconnection requires a redrawing of the whole continent's communication system, based on the creation of corridors to allow a transport network. With such infrastructural integration, states not only compromise their territorial sovereignty but also their identity. The risk of this transnational project could be a partial dissolution of nation-states. The best-known project of transport lines between the Atlantic and the Pacific and between North and South America is the "Puebla-Panama Plan" through the Tehuantepec Isthmus and Chiapas.

In US representations, the process of intercommunication between South and North America seems impossible because of the inability of some states to guarantee security on their own territory. The implementation of the FTAA, or of any free-trade project, not only implies the elimination of physical obstacles but also of political, social and military ones to delay the establishment of a free-trade zone. The United States needs to face these "disorders". At the end of the twentieth century, US policies for the region illustrate the Monroe Doctrine corollary: Teddy Roosevelt's big stick, legitimised by an idealistic interventionism à la Wilson.

\section{TRADE AND SECURITY: NIHIL NOVI SUB SOLE?}

The market economy and liberal democracy constitute the basic elements of the US representation of the world. They make up the axes of US foreign affairs and are components of its national security strategy; they go beyond the Republican-Democrat divide. The US macro-strategy for the region combines trade with military actions. After the Cold War, with the transformation of the conflict and the concepts of power, the United States re-adopted a 
traditional definition of national security. This is a classic geopolitical Pan-Americanist view, inspired by A. Mahan, in which the main idea is the combination of international trade with armed forces. (40) However, the United States also accentuated a characteristic of the Cold War: the continentalisation of security.

The conditions for a military offensive strategy, according to the expansion of liberal democracy and the market economy, were already settled when George W. Bush was elected US president. Former president Bill Clinton had not hesitated to state that trade was a priority for America's security, declaring that US economic and security interests were inextricably tied. (41) After the 30th Conference of America's Council in Washington, DC (May 2000), Clinton asked the Latin American countries to support "Plan Colombia" and to establish a close relationship between regional security, which had been upset by the Colombian conflict, and the effort to create a free-trade zone.

Since the beginning of the 1990s, the war against drugs has been related to free trade. The threat of "narco-terrorism" is a key element of the US strategic device in the Andean region. It was within this framework that the first Bush Administration had set up "the Andean Initiative', whereby military aid granted to the Andean countries was accompanied by trade agreements. Behind its name, which is more trade- than security-oriented, the Andean Trade Preferential Act (ATPA) hid more military than economic aspirations. The agreement, renewable annually depending on the level of co-operation of the states involved in the war on drugs, is aimed at the substitution of coca crops in order to limit the production of cocaine and its traffic. (42) More than a free-trade agreement, it acted as a unilateral commercialpreference agreement that allowed products from Andean countries to enter the US market thanks to preferential customs rates. (43) Following the expiry of the first agreement in December 2001, a new one was signed in November 2002. The new denomination, Andean Trade Preferential Drug Eradication Act, betrays the primacy of Mars on Mercury. In the new agreement, the substitution of the coca-leaf crops is replaced by the forced eradication of these crops. It also includes support for "Plan Colombia" and the possible installation of US bases in the area.

In 2005, during the visit of US Secretary of Defense Donald Rumsfeld to Peru, President Toledo maintained that the fight against the traffic in drugs was to be accompanied by the support of the US Congress for the Free Trade Agreement. Toledo and Rumsfeld stressed their commitment to fight the drug trade and terrorism together, while Rumsfeld said that Peru was a leader in the area in the fight against "terror" and Toledo connected the FTA with the substitution of coca crops. Peruvian politicians, who underlined Peru's lack of resources to battle the drug trade, asked that the United States work out a "Plan Peru", and the Peruvian Prime Minister underscored the need for logistical support, stressing that the assistance received by Peru is very weak compared to that given to Colombia. Rumsfeld's visit was accompanied by a debate on immunity for US troops as a condition for signing the FTA with Peru. Thus, the relationship between geography, economy and security still seems to determine US geopolitical expansion. The transnational representation of Latin American territory is based on three subsystems, Central America-Caribbean, Andean-Amazonian zone, South America, that must be integrated in accordance with the ideology of enlargement and globalisation. In terms of geopolitics, the Central America-Caribbean subsystem is the principal zone of interest for the United States. It has always been considered a border area; historically, the region has been thought of as a "mahanist" type of geopolitical representation. It was central to the US expansionist policy that related to the need to make its 
borders safe and guarantee its economic interests, the corollary of which was the policy of occupation and protectorate. In the 1930s, the "Good Neighbor" policy of Franklin Roosevelt was a relative exception. (44)

Currently, illegal migration, drug trafficking, organised crime and a strong Latin American lobby in the United States are the reasons why Mexico, Central America and the Caribbean play such an important role in US domestic issues. (45) There is an intense relationship between the economic interests of the countries of these regions and the United States, and their economies are completely oriented toward the US market.

As a direct consequence of NAFTA, the Mexico-US border has been opened to the exchange of goods that are difficult to control; at the same time, this fortified border works as a barrier to migrants. Thus, Mexican migrants are kept inside their country, working in the maquiladora system, in which delocalised US industries profit from the comparative advantages of cheap labour and competitive prices. The reconfiguration of this economicsecurity space may foreshadow a second line of maquiladoras that would enable the control of migrant movements from Andean and Central American countries.

In late 1980, in its fight against drug trafficking, the United States widened the traditional "Mediterranean" area toward the Andes. By the end of the twentieth century, its fight against narco-terrorism had led it to enlarge its area of influence toward the Southern Cone. The transnational dimension of the US strategic representation is observed in the Andean-Amazonian case, viewed as an area that is not divided into traditional national territories. The US representation of this zone is based on a geopolitically unified description of the Amazonian Andes, which is, geographically, the heart of Latin America. This dimension is at the centre of the new military architecture in Latin America. The change of name from "Plan Colombia" to "Andean Regional Initiative" (ARI) in March 2001 reveals the transnational character of regional conflict representations in the current Bush Administration.

With this change of denomination, we are facing a major modification in the use of force: from a struggle against narcos and guerrillas that threatened the security of only one state to a regional project that focused on the pacification of the whole region and is becoming a global and cross-border conflict. As far as the United States was concerned, the capacity of the armed forces of the Andean countries was considerably reduced in the 1990s.

The importance of the area cannot be dissociated from the regional geopolitical transformations. The main loci of instability in Latin America that represent a threat to US interests were located during the 1970s in the Southern Cone and during the 1980s in Central America. At the end of the twentieth century, the Andean area was the main strategic concern.

The creation of the ARI was a fundamental moment in the design of the new US strategic thought. The Andean-Amazonian area exposes this dialectical relationship between the regional and the global that has characterised US action in the post-Cold War world: The confrontation is always total in its essence but always regional in its manifestations.

Since the end of the 1990s, difficulties in implementing the policy of enlargement, especially the economic integration aspect of it, have strengthened the influence of the Pentagon, the CIA (Central Intelligence Agency) and the DEA (Drug Enforcement Administration) in Latin America. The number of soldiers sent on missions, permanent contacts between armies, joint manoeuvres, installation of military bases and material 
purchases provided evidence of the importance of "high politics" for the United States, as was the case during the Cold War. The United States was once again attempting to confirm its hegemony on the continent through its military power. Its efforts to establish collective defence mechanisms for multinational operations were accompanied by an increase in the number of multilateral security organisations: Inter-American Council of Defense, Committee for Hemispherical Security, Inter-American Committee Against Terrorism, biannual meetings of the ministers of defence, meetings of heads of state, and so on. This policy implies diplomatic immunity for members of the military; as such, the host country must renounce its jurisdictional power to investigate possible offences and sue the US government at the International Court of Justice. This demand has raised discussions on national sovereignty, one recent example of which is the Paraguayan case of June 2005. (46)

The United States has always defended its national interest by the use of force. (Its refusal to use force in the 1930s is an exception.) The US power of intervention in Latin America gives a specific character to the region, although during the post-Cold War period, it has had fewer incentives to interfere because of the weakening of anti-system actors, such as guerrillas supported by foreign states. Nevertheless, the United States is free to interfere in the continent because there is no opposition bloc that could refuse its actions and because of the validity conferred by the struggle against terrorism. The different "wars" (against terrorism, drugs, organised crime, etc.) have confirmed the US idea of legitimate interference under the threat of the use of force and/or economic sanctions.

Through its military presence in the region, both direct and indirect, the United States assures its influence in a zone that is vital to its interests. Military deployment performs a dual role. The first is gaining access to strategic territories such as the Amazon region in order to control the area's many natural resources, both traditional (oil, gas) (47) and hypothetic (water and biodiversity). In 1996, at the Conference of American Armies, Pentagon chief W. Perry declared, "The region is a source of vital resources for our security and our welfare". The second role of military deployment, which is closely dependent on what precedes it, is the establishment of a mechanism of control over any movement that is considered a threat to regional security and to the establishment of a free-trade zone.

\section{THE ADMINISTRATION OF “DISORDERS”}

Global action to consolidate political and economic stability, and stimulate their development according to US interests, implies the control of movements opposed to neoliberalism. The strength of US military forces in Latin America can be explained by the increase in social conflicts related to the economic policies of the 1990s.

The symptoms of political and social crisis in Peru, Ecuador, Bolivia and Argentina, the current situation in Colombia, and the mistrust of Venezuela by the United States all exert an important impact on the US strategy of control over populations with a strong tradition of insurrection. In the last few years, popular uprisings, with different levels of organisation and different demands, have disrupted Latin America. These social movements have emphasised the decline of political systems and regimes that have lost legitimacy due to their inability to satisfy social demands.

US security policies have targeted the different movements against neoliberalism 
that developed during the 1990s. According to the US view, these movements are the result of democratic reforms that did not satisfy people's needs. Acknowledging this popular dissatisfaction, R. Noriega, the assistant secretary of state for the Bureau of Western Hemisphere Affairs, stated that US policies for the region must face up to problems such as poverty, illiteracy and security. He also maintained that democracy and the free market guarantee a better quality of life in the hemisphere. (48) The failure of Latin American countries to adapt to the enlargement of liberal democracy and the market economy is the axis of US perception. The states of the region are weakened by fragile institutions and economic difficulties. This concept expresses the key idea of the new US national security doctrine: There is no mechanical relationship between poverty and terrorism, but poverty, weak institutions and political corruption make states vulnerable to terrorists and criminal organisations.

In the post-Cold War period, some strategic issues appear as just updates. Viewing poverty as a security question to be answered by the military - discussed, for example, during the American Armies Conference in 1996 - is not new. Security and economic development have been closely bound since the late 1960s. For Robert MacNamara, development was the "essence of security", (49) a thought that was supported, for example, by General O. Villega, the secretary of the National Security Council of the Ongania government of Argentina.

In this context, besides the traditional threats such as terrorism, corruption and organised crime, an emergent threat in US representations is defined as "radical populism".(50) This threat undermines the democratic process by reducing, instead of increasing, individual rights. According to General Hill of the Southern Command, (51) this political tendency is carried on by some leaders who "take advantage of the deep frustrations owed to the democratic reform failure. By exploiting these frustrations, leaders are reinforcing their radical positions while increasing the anti-American feeling". He gave as examples countries such as Venezuela, Bolivia and Haiti but also had numerous concerns about neoliberal reforms. According to General Hill, the anti-American feeling has been used to reinforce radical leaders. He added, "we will continue to work to improve the military capacities and professionalism of our allies, so that they can maintain their own security and fight against common transnational threats".

The answer to this social instability, according to Hill, is to "help allies to face these threats and the structural factors that underlie them, by cooperation". This interpretation illustrates the traditional distrust of the United States for popular mobilisation and mass political involvement in Latin America. According to the US representation, radical populism undermines the democratic process by reducing individual rights: Social questions are always individual because they are seen as individual demands on the political market.

Groups opposed to neo-liberalism and the FTAA - the MST-Sem Terra (Brazil), the Círculos Bolivarianos (Venezuela), the Pachakutik (Ecuador) or the MAS (Bolivia) - are typified as radical populist movements. These movements are unified under the US political and strategic representations for Latin America. They are considered to be "new threats", threats that represent the reappearance of an old-fashioned left that has nothing to do with the moderate and liberal left-wing Socialist Party of Chile.

Despite having a universal influence (the experience of Venezuela's Chavez is a model not only for other Latin American social movements but also for different political and social organisations), these movements do not aspire to become universal. In contrast to the 
traditional left, they have neither a unique ideology nor universal intentions; each one is created according to its own political culture, more or less influenced by nationalism. However, although the structures of these movements are different, their centres of gravity are close to each other in that they share the same view of the national and world reality, their national character is compatible with the development of transnational resistance, they promote the construction of communication networks and transnational interactions and they are related to the new methods of political-social protests, such as the anti-globalisation movement. The most meaningful expressions of this were found at the World Social Forum of Porto Alegre. Although these movements are based on local traditions, their worldview links them to a worldwide movement, without losing sight of national or regional questions. They support the idea of national identity in a revolutionary "messianism" that is adapted to the present condition and characterised by the lack of a worldwide revolutionary project.

Those who oppose these movements attempt to discredit them by accusing their leaders of being involved in terrorism and drug trafficking. Apart from permanent accusations of an understanding between Hugo Chavez and the FARC guerrillas, other hypotheses have linked him with narcos. In 1999, General B. McCaffrey, head of the Office of National Drug Control Policy (ONDCP), referred to possible ties between Chavez and drug dealers, this information was subsequently denied by the US embassy in Buenos Aires. (52)

The US ambassador has constantly criticised Bolivian Evo Morales. Since 2001, there have been ongoing "rumours" about the formation of irregular groups financed by Chavez and narcos in the Cochabamba area of Bolivia, specifically the Chapare-Yungas project, where the region was said to have been turned into a cocaine-production zone under the protection of guerrillas in collaboration with the MAS movement. According to these rumours, which became more significant after the Bolivian crisis of 2003, guerrilla camps were being formed, there were plans to murder DEA agents and cocaleros (coca growers) and other groups were armed with the intention of seizing private property. The aggressiveness of the Federaciones cocaleras and the intensifying social conflict were also rumoured to be part of this project. (53) President Toledo of Peru took several opportunities to denounce the Etnocaceristas, whom he said were being financed by drug dealers and wood smugglers.

\section{LAW AND SOVERIGNTY IN POST-COLD WAR LATIN AMERICA}

The willingness of the United States to impose its system of representations, which rests on a weakened concept of rights and sovereignty, touches on the concept of international relations that is conceived as an interaction between sovereign states founded on the principles of non-interference, non-intervention, respect of borders and equality and reciprocity between nation-states. Questions of sovereignty became a concern with the hypothesis of a military intervention in Colombia at the end of the 1990s.

In the United States, the war against terrorism refocused and centralised state power and this meant building an apparatus to protect and stabilise traditional notions of territory. In Latin America, (54) 9/11 accelerated the reforms of continental institutions created at the beginning of the Cold War. This acceleration required weakening the traditional conception of sovereignty while taking into consideration concepts such as "grey zones" or "ungovernable zones", both deeply rooted in a key idea of the strategic debate taking place in the post-Cold War United States, that is, the "failed state". 
According to the US strategic representations, Latin America is an area where grey zones allow "new threats", especially terrorism, to be implanted. The concept of ungovernable zones was a central question during the regional defence ministers meeting held in Chile in November 2002, but a consensus was not reached on this motion. On this occasion, countries such as Brazil and Venezuela declared their opposition to the concept.

The "failed state" concept was born in US think-tanks during the 1990s. It means an "unstable" state, one that is unable to put its own affairs in order and that represents a threat to the global system. This concept confers to the United States the legitimacy to intervene in that state as it does with "rogue states".

According to the US representations, the institutional weakness, the fragile state control and the economic problems of the failed state lead to political corruption, to patronage systems and to illicit activities in Latin American states. However, all these features must be considered in the context of a global system that is increasingly subjected to liberal dynamics. In the case of Latin America, difficulties controlling territory must also be related to neoliberalism. The widening of zones where the state cannot exert direct control any longer was stimulated by the policies of the 1990s.

The failed state is characterised by a lack of all official structure that could guarantee order and of what M. Weber called "the exercise of the monopoly of legitimate violence". If the paradigmatic example of a failed state is Haiti, this category has been increasingly used since 2002 to explain the situation of social conflicts in the Andean countries. The signs of crisis in these countries have allowed the United States to describe them as failed states. At the end of 2005, the transfer of Bolivian missiles to the United States to be destroyed is representative of Bolivia being considered a failed state.

The fact that the state is no longer able to exercise its monopoly of legitimate violence enables the rise of transnational actors developing illegal activities, which subsequently structures the zone's economy. This is connected with a post-Cold War tendency: Criminal organisations (55) are trying to find new areas of operation to develop their highly profitable businesses. Globalisation is accompanied by new internationalised criminal elements, organised by cells. Some features of neo-liberalism and globalisation such as free circulation of capital, emerging markets and frequent indifference of banking sectors and financial institutions to corruption promote illegal business. In Latin America, illicit business contributes to increase regional destabilisation, as can be observed in the Colombian case as well as others, a situation that can be compared to those of Central and South East Asia.

The installation of free trade zones seems to stimulate criminal activities. Smuggling activities, in particular, drug trafficking, have been discussed in Maicao (Colombia), Colon (Panama), Iquique (Chile), Chui (Uruguay) and the Triple Frontera (Brazil, Argentina, Paraguay).

This inability of states to control a part of their territory can result in more regional instability, although in a less obvious way. In the cases of Paraguay (56) and Surinam, Latin America has revealed a phenomenon of strategic value that is spreading in the underdeveloped world: states recognised by the international community and legitimately organised that nonetheless allow the development of illegal activities. This type of state assumes an accomplice position, that is, it builds an institutional link that implies the 
"protection" of illegal groups while profiting from the illegal activities developed on its territory.

In general, geography dictates the appearance of ungovernable zones, but it is not the only determining factor. These zones exist in areas that are difficult to access and not fully integrated into the national territory, which makes the development of clandestine activities easier. Usually, these zones are directly related to border areas: the region of Tabatinga and Leticia (Brazil, Colombia and Peru), the region of Darién (Colombia-Panama), the region of Lago Agrio (Ecuador-Colombia), Maicao (Colombia-Venezuela), the Tartagal-Orán region (Argentina-Bolivia) and the Triple Frontera (Argentina-Brazil-Paraguay). Early in the twenty-first century, the Paraguayan Chaco became a new "ungovernable" zone. The United States reacted to its formation by doubling its pressure on the Paraguayan government; US military manoeuvers with the Paraguayan army in June 2005 and its use of the M. Estigarribia military base are recent examples of the US presence (57) in this country. (58)

The Triple Frontera (59) is a "paradigm" of an ungovernable zone. Formed in the 1990s in the context of the Colombian conflict, the Triple Frontera illustrates the similarities between the Democrat and the Republican representations. In 1999, the anti-terrorism coordinator of the Department of State, Mr. Sheehan, notified the Argentinian government of US concerns about the increasing presence of terrorist and drug-trafficking groups in the region. In 2000, the United States maintained that if the moderate sectors in Iran were to be victorious and a peace agreement were to be signed between Israel and Syria, members of Hizbullah could immigrate to the Triple Frontera region and make contact with local criminal groups. (60) In the context of the war against terrorism, the United States notes that there are Islamic groups in the Triple Frontera, arguing that the ties between drug dealing and the FARC will be increased by the war in Afghanistan. The damage caused to heroin trafficking by the Afghan war has promoted an alliance between Colombian drug dealers and Islamic terrorists in order to develop and maintain the production and commercialisation of drugs. (61) In 2003, General Hill of the US Southern Command said that narco-terrorism activity was fuelling radical Islamic groups associated with Hamas and Hizbullah militants who were operating in such places as the tri-border area of Brazil, Argentina and Paraguay and on Venezuela's Margarita Island. (62)

Clearly, the Triple Frontera is a security concern, based on the threat of criminal networks linked to Islamic fundamentalist groups setting up in the region, of the presence of sleeping terrorist cells, of operation fields for new attacks, (63) of activities financed by Islamic contributions and of illegal businesses. (64) Since the 1992 and 1994 attacks against the Jewish community in Buenos Aires, the zone has been under control. As of 1999, the Argentinian intelligence services have been looking for traces of and connections to Osama Bin Laden. US intelligence services maintain that the authors of the terrorist attack in Luxor, Egypt, in 1997 found shelter in the Triple Frontera. Hassan A. Mokhler, who was accused of having participated in this attack, was caught on the border between Brazil and Uruguay for carrying fake identity papers; his wife has always lived in the zone. Another suspect in this attack was later arrested in the region.

Under US pressure, a Joint Security Command was created by the countries of the region. Brazil and Argentina have deployed important security mechanisms in order to prevent criminal actions from threatening their vital tourism industries. These mechanisms are used in an integrated way: national and state police forces, intelligence services, customs control and private security agencies for hotels and other tourist infrastructures. A contingent of Argentinian intelligence services staff works closely with their US counterparts. However, 
terrorist activity in the Triple Frontera has never been demonstrated. The United States has been unable to prove the existence of terrorist cells and the local armed forces have denied the presence of terrorists in the zone. According to some political and non governmental organisations, (65) US interest in the zone is related to the control of natural resources and access to drinking water. Researchers have revealed that there is a huge supply of drinking water in that zone, in the Acuifero Guaraní, which is probably the most important reserve in the world.

Taking into account that these are bordering states, co-operation between them is crucial in order to stop the spread of criminal activities. The lack of state presence exercising efficient sovereignty does not imply, however, that the Triple Frontera zone is ungovernable.

According to the US representations, Latin American states have difficulty acknowledging what is happening in their territory; to solve this situation, they must receive foreign aid. (66) But these representations are not exclusively those of the United States. At the end of the peace process, Colombian authorities requested that the conflict in Columbia be internationalised, even more so after the military intervention policy of the United States and the war in Iraq. (67)

Colombian President Alvaro Uribe asked for an international intervention in the region, warning that Amazonia could be soon destroyed by terrorist actions. During his visit to Brazil in 2003, Uribe pointed out the risk that drug terrorism represents for the ecosystem and that it will be responsible for the destruction of Amazonia.(68) At the 2003 Davos Summit in Switzerland, Uribe declared that the situation in Colombia would soon be far more threatening than that in Iraq and that narco-terrorism is the major threat to the Amazonian area.

Thus, the environmental issue appears to be a suitable mechanism to justify foreign intervention under the guise of co-operation in the context of regional and global interdependence. Environmental protection can also be linked to the war against terrorism and drugs because the destruction of pipelines (a tactic used by the ELN) and the activities of the drug culture can be understood as "environmental terrorism". (69) The role of environmental issues in the redefinition of military actions in the region was highlighted in a May 2002 meeting in Paraguay and a May 2003 meeting in Uruguay, organised for the US Southern Command and the US Environmental Protection Agency (EPA). These meetings revealed a new US representation, one that sought civilian-military co-operation opportunities for environmental protection in South America. Bearing in mind the premise that South America will become a genetic and water reservoir, this representation maintains that the defence of sovereignty will no longer be limited to border protection.

The environment and the ecosystem will be of increasing importance since an environmental impact on a single country could affect others due to its global character. National armies must protect every country from a regional perspective, working together to defend sovereignty. However, Washington is finding it difficult to persuade Latin American countries of this new role for environmental issues. For example, Brazil was present at the meeting in Paraguay, but did not attend the following one in Montevideo. The position on human global interests cannot be easily supported by a country that has boycotted the Kyoto agreements and underestimated the environmental consequences of "Plan Colombia".

\section{RESISTANCES}


The determination of the United States to impose strategic and political representations that rests on a weakened idea of law and sovereignty takes different forms and moves beyond the question of security. During the 35th OAS General Assembly in June 2005, the United States suggested, with no success, that a multinational forum be created to solve the Bolivian and Ecuadorian crises by adopting measures that implied an interruption of sovereignty. It suggested that a Special Committee of the OAS should monitor the evolution of democracy in the hemisphere through mechanisms that would allow civil organisations to inform the forum directly. US Secretary of State Condoleezza Rice stated that democratic elections were not enough and that the OAS should supervise the activities of democratic governments. Even though this multinational project does not mention coercive measures, either sanctions or military actions, it does give the Special Committee and the General Secretary the authority to elaborate plans of action in order to solve the problems of Latin American democracies. It should be noted, however, that the Charter of the OAS establishes the non-intervention principle, that is, a state's right to choose without external interference its political, economic and social systems and its position against war. The project has encountered resistance from Brazil, hesitation from Argentina and radical opposition from Venezuela, whose government thinks that the project has been promoted to allow US intervention in its country.70 Argentina acted as mediator between the US position and those of countries that considered the initiative to be interventionist.

Venezuela and Brazil, which adhere to a "modern" definition of sovereignty and selfgovernment, believe that the sovereignty principle is essential if the different political systems are to avoid having to submit to a universal 'empire' that could be oppressive. Decision makers at strategic levels, restricted to a 'modern' order of interaction between sovereign states, according to the Westphalia System, have resisted the transformation of the sovereignty idea. These countries do not accept the concept of absence of effective sovereignty, nor of measurements that imply a tacit suspension of sovereignty. For these countries, state sovereignty cannot be relative.

The economic and military integration agreements signed between Venezuela and Brazil in February 2005 were directly connected to the US policies for the region, even though the leadership projects of Brazil's Lula and Venezuela's Chavez and their national interests are very different. Brazil is seeking a regional leadership based on consensus, whereby it considers its neighbours' national interests and the need to reach a consensus on an autonomous regional development project that is based on an equitable distribution of costs and benefits but without confrontation with the United States. Brazil has tried to maintain the role of mediator between the United States and Colombia on one side and Venezuela on the other.

Brazil denies the idea of weak states and ungovernable zones and the absence of effective sovereignty over its territory. In 2006, at the Armies Conference at Montevideo, comments by the chief of the US Southern Command on the existence of "empty spaces" in the Amazonian region provoked the reaction of the Brazilian military delegation. (71) Brazil does not accept the idea of the Triple Frontera as a terrorist base, although it is constantly mentioned in US State Department documents on terrorism.

The strategy of the United States not only affects a fundamental principle of Brazilian diplomacy (national sovereignty and non-intervention) but also a key question for Brazilian defence and national interest: Amazonia. During the Chancellors' meeting of the Organization of the Treaty of Amazonian Cooperation in 2004, the question of sovereignty was related to 
the issue of natural resources. According to C. Amorin, Brazilian foreign affairs minister, Amazonian countries are the "sovereign guardians" of humanity's natural resources and they have the right and the duty to promote sustainable development in the region. He emphasised that security is a fundamental issue for the region and referred to border protection and the trafficking of biological resources as permanent threats. The subsequent "Declaration of Manaus" assures the full exercise of sovereign rights on resources.

In the 1990s, US policies caused the resurrection of archaic perceptions in Brazil. The Forward Operating Locations, the designation of Argentina as an extra-NATO ally of the United States and the military exercises that followed provoked a perception of geopolitical suffocation in Brazil. The policy of the United States in the subcontinent and the Argentinian position on that policy during the Menem Administration brought back old strategic representations that date from post-colonial times. According to this perception, Argentina has always tried to isolate Brazil by forming a Hispanic bloc under its own direction. The possibility of an anti-Brazilian alliance carried on by Argentina has always been present, from the Baron de Rio Branco to M. Travassos.72 Brazil and Argentina are medium powers and share the same area of influence, so establishing pre-eminence over one another depends solely on their individual relationship with the United States. However, in post-Cold War, this situation has neither encouraged military and geopolitical confrontation nor strengthened the perception of threat linked to the "neighbourhood logic" that has characterised the region, in particular, during the second half of the twentieth century.

\section{CONCLUSION: IS LATIN AMERICA A STRATEGIC LABORATORY?}

Since post-colonial times, the Latin American perception of threats and its impact on defence policies have been associated with national border changes and the idea of conflict and power changes on the continent and in the rest of the world. In Latin America, the enhanced value of frontiers at the strategic level must be examined in relation to both the nature of the post-Cold War threat and US strategic representations.

Numerous factors determine US geopolitical expansion in Latin America: access to foreign markets and natural resources, protection of US economic and financial interests, the pressure over the Latin American governments' intended implementation of economic reforms aimed at opening their economies to foreign investment and trade, guarantees requested by the United States to counter these investments, the US relationship to extraregional powers and, finally, the obstruction of all autonomous political alternatives, some of which were important aspects of nineteenth-century foreign policy.

Thus, it appears that the transnational dimension of the strategic representations promoted by the United States does not correspond to the traditional concept of national territory. This concept, which is the basis of the reshuffling of military architecture in Latin America after the Cold War, is rooted in a representation of the region that has been present since the 1940s but was systematised under the Democratic Clinton Administration in the 1990s and further developed under the presidency of Republican George W. Bush in the early twenty-first century.

Latin America illustrates that the US strategic model is shaped by norms and rules that tend to restrict national sovereignty through global decision-making bodies whose aim is to guarantee the security of the ways and means of the global economy. US strategic 
representations and practices, by unifying "internal" and "external" aspects of security, build on the transnational character of supply and demand for security. These representations, focused on transnational aspects, seek to deconstruct national sovereignties that constitute republican states. Although compatible with the development of cross-border projects, they do not necessarily coincide with the regional integration policies of Latin American states.

The leadership of the United States promotes a double process: on the one hand, segregation within nation-states by means of political secession and, on the other, reunification by means of an economy of regional mega markets. The US macro-strategy presents two complementary dimensions: the weakening of national authorities and the rebuilding of a vaster unit on the basis of the market. This promotes a scale of balkanised organisation where political actors have little autonomy, while establishing macro-financial borders like the dollar area (the simplest form) or free-trade areas like the FTAA (a more elaborate form). (73)

Since 1990, the US government has intensified its military deployments and reinforced military alliances in Latin America. Military deployment is an important piece of the neoMonroe Doctrine strategy. This strategy stresses the notion of both territory and physical presence in a way that contradicts the trust in technology that emerged from the first Gulf War and was demonstrated triumphantly in the "Revolution in Military Affairs". The US strategy for Latin America is founded on an "archaic" (from its etymological sense of "beginning") characteristic of domination: the territorial establishment.

In Latin America, the United States has used drug trafficking, organised crime or terrorism as a reason to redefine regional security, starting from a transnational representation of conflicts and space that is closely related to the construction of a free-trade area. The United States has adopted a policy based on the preventive control of popular movements against liberal orthodoxy. However, if under the influence of the United States, the dynamics of security in the Southern Cone have become largely regionalised and new US representations have a role in the construction of strategic doctrines to occupy the vacuum left by the abandonment of the Doctrines of National Security, then we are still far from the consensus of the Cold War period and it is why there is diplomatic pressure to make local security agendas compatible with the US agenda. At the beginning of the twenty-first century, except for its relationship with Colombia, the United States is having difficulty establishing a system of alliances similar to the system it established with Brazil during the Cold War or with President Menem of Argentina immediately after the Cold War.

According to US post-Cold War strategic thought, the previous status given to Latin America no longer coincides with its historically weak military position. In fact, the United States has tested a series of post-9/ 11 strategic concepts, used on a global level, in the region. Thus, Latin America is not only a region traditionally controlled by the United States but it is also a strategic "laboratory", representing a complex area in which the United States has tested empirically its general global representations. During the 1990s, the Balkans served as a similar experimental zone.

Latin America has had a role in the institutionalisation of an expeditionary practice founded on military action that, even though it was taking place locally, acquired a global significance upon which rests the post-Cold War hegemonic role of the United States. Some of the most evident elements of the strategic plan developed by the United States in the context of its "National Security Strategy" were already present in Latin America during the 
1990s: the territorial control through military bases, the use of non-governmental organisations for strategic purposes, the promotion of intervention through peace-keeping operations, military operations other than war, the transnational character of space, the private military operators and the diplomatic pressures to adjust local security agendas to US strategic interests. In addition, the concepts of "grey zones" and "failed states" and the transnational character of threats such as narco-terrorism, organised crime and the destruction of the ecosystem served as a justification for US interventionism, as well as for the redefinition of the functions of Latin American armies.

The strategy used by the United States since the 1990s revealed the foreign policy that the US developed openly after 9/11. This policy implied increased US intervention in regions where its national interests were at risk (as in the Middle East) and the reinforcement of its military presence (as in Central and Pacific Asia). The US security strategy rests on the control of peripheral areas through stabilisation operations and implies a terrestrial presence by a redeployment of military forces. At the end of the twentieth century, the United States, modelling its Colombian policy, prepared its interventions in the world of the twenty-first century, later illustrated by its direct military actions in Liberia, Djibouti and the Philippines.

However, the temporalities of Latin America and the rest of the periphery differ. The Latin American subcontinent has been the vanguard of neoliberal policies. Before this doctrine became a hegemonic ideology, it had been adopted in the subcontinent, especially in Chile and Argentina, in the 1970s. Early in the twenty-first century, the Middle East is slowly starting the process of liberalisation and integration into the global world, a process that is further accelerated by the war against terrorism.

Any post-Cold War strategic analysis must take into account the importance

of neo-liberal policy. Ironically, the US strategic representations do not consider the impact of neo-liberal policies on the weakening of the state. The new threats - criminal organisations, from guerrillas to terrorist groups - take advantage of the global system, that is, the global world and the regional economies that have resulted from the liberalisation process promoted by the United States. 


\section{APPENDIX}

\section{FIGURE A1}

Main geopolitical tensions in the post-Cold War period.

\section{FIGURE A2}

Security facilities used by the United States in the post-Cold War period.

\section{FIGURE A3}

Zones of nongovernability and failed states according to United States Strategic Representations.

\section{NOTES}

1. Strategic representation is understood as the idea of power relations within the international system and society that all actors in a particular institution (political party, army, labour unions, etc.) develop. It appears as a dynamic process that illustrates how history is interpreted and how international relations are perceived and it defines priorities based on national and subnational values and interests. "Representations" are more than the simple ideas and beliefs of decision makers. They are material entities, each consisting of a network of expository relations that can be described and analysed from speeches and actions. Moreover, representations are the consequence of speeches and beliefs held by decision makers, and they can be changed by new ideas. While a belief implies a first level of analysis, a representation implies institutionalisation. Strategic representation is the way in which social groups symbolise their realities subjectively in terms of different power configurations: social, institutional, territorial, demographic, economic, military, etc. Such representation symbolises the external reality; it is the process by which a perception is introduced into a rational global interpretation, which subsequently results in decision making. Strategic representation is descriptive rather than interpretative; it illustrates the "doxa" rather than the "episteme". See E. Manero, L'Autre, le Même et le Bestiaire (Paris: L'Harmattan 2002) ch. III.

2. Newspaper editorials are clear examples of South America's concerns about borders. See, for example, Clarín, Buenos Aires, 11 June 2005.

3. On this topic, see the works of A. Joxe, especially L'Empire du Chaos (Paris: La Découverte 2002).

4. See E. Manero, «La reconversión de las identidades militares en América Latina en los 90 o el atemporal tema del traidor y del héroe », in A. Férnandez (ed.), Globalización, fragmentación social y violencia (Rosario: Homo Sapiens 1997) pp. 99-116.

5. About strategic transformations in Latin America, see S. Fitch, The Armed Forces and Democracy in Latin America (Baltimore: The Johns Hopkins University Press 1998); J. Tulchin and R. Espach, "Latin American in the New International System: A Call for Strategic Thinking", in J. S. Tulchin and R. H. Espach (eds.), Latin American in the New 
International System (Boulder, CO: Lynne Rienner 2001); R. Diamint, La Otan y los desafíos en el Mercosur. Comunidades de seguridad y estabilidad democrática (Buenos Aires: GEL 2001); R. Diamint, "Security Challenges in Latin America", Bulletin of Latin American Research 23/1 (Jan. 2004); D. Pion Berlin, "Political Management of the Military in Latin America", Military Review (Jan.-Feb. 2005).

6 . The representations studied here are not seen as an isolated element but as a constituent part of the area's political history. They are inseparable from the concrete actors who are involved in them - the military - and from interactions between social classes and countries on the continent. These strategic representations are the basis of decision making. The question is, could representations and practices be strictly separated? This refers to the ancient distinction between men's ideas and their acts, but it has no basis. From Wittgenstein, we know that games of language are composed of linguistic exchanges, as well as the actions in which these exchanges are implied. It is in that sense that we refer to strategic representations as structured sets that articulate both speech and practical elements. Thus, representations and practices cannot be strictly separated.

7. Strategic culture can be defined as a long-standing process of action and reflection, developed by a group according to the particular way in which it solves its relations with nature, with members of the community and with other communities in order to give continuity and sense to its existence while guaranteeing the survival of its "identification collective". Strategic culture encompasses all of the attitudes, norms, beliefs, customs and values related to the idea of "Us" that are shared by the members of a social unit. That is, strategic culture implies a way of thinking about what individuals or collective actors would do if facing the "threat of death". See Manero (note 1) p. 53.

8. Dominguez's work focuses on international regional institutions and procedures that facilitate interstate peace. The panoply of procedures and institutions evident in interAmerican relations explains the infrequency and short duration of interstate wars. InterAmerican peace-keeping institutions have been very effective, and the structure of the international system in South and Central America explains the rarity of war. J. I. Domínguez et al., "Boundary Disputes in Latin America", Peaceworks 50 Washington,

DC: United States Institute of Peace (2003).

9. A. Joxe, «Les Yougo-frontières de l'Europe et l'identité démocratique », Cahier d'Etudes Stratégiques 19 (1997) p. 13.

10. For more about the history of Realism, see D. S. Yost, "Political Philosophy and the Theory of International Relations", International Affairs 70/2 (1994) pp. 263-90.

11. H. J. Morgenthau, Politics Among Nations (5th ed.) (New York: Knopf 1978).

12. A. Joxe, Le cycle de la dissuasion (1945-1990). Essai de stratégie critique (Paris: La Découverte/Fondation pour les études de la défense nationale 1990) p. 51.

13. F. Thual, Géopolitique de l'Amérique latine (Paris: Economica 1996) pp. 36-37.

14. K. Von Clausewitz, De la guerre (Paris: Minuit 1998).

15. C. Lafer, "La Problemática Argentino Brasileña" in Archivos del Presente 2/8 (1997).

16. This refers to the vast system of exchange of prisoners and information developed by the armies of Chile, Argentina, Brazil, Uruguay, Bolivia and Paraguay.

17. See E. López (ed.), Seguridad Nacional y Sedición Militar (Buenos Aires: Legasa 1987).

18. D. Mares, Violent Peace: Militarized Interstate Bargaining in Latin America (New York:

Columbia University Press 2001), ch. 3.

19. Domínguez (note 8).

20. Clarín, Buenos Aires, 16 Feb. 2005.

21. Report XXXIII, OAS General Assembly, Santiago de Chile (June 1991).

22. Limiting NBC weapon proliferation (avoiding the transfer of advanced technology to hostile nations) is a long-standing goal of US security policy. For Washington, the problem 
was to restrain Argentina, Brazil and Chile; these countries categorically refused to sign the Treaty of Tlatelolco. The Clinton Administration made the non-proliferation of weapons of mass destruction one of its central goals.

23. V. Beltrán, «Buscando nuevos roles para los ejércitos de América Latina », SER en el 20004 (Sep. 1993).

24. In 2005, during the 17th meeting of the Secretaries of the Interior, of MERCOSUR and of associate countries, co-operation agreements were signed to begin the process of increasing coordination in areas of security and migration policies. Clarin, Buenos Aires, 4 June 2005.

25. G. W. Hegel, Principes de la philosophie du droit (Paris: Gallimard 1940).

26. E. Luard, The Blunted Sword. The Erosion of Military Power in Modern World Politics (London: Tauris 1988).

27. See B. Badie, La Fin des Territoires (Paris: Fayard 1995).

28. See Domínguez (note 8).

29. O Estado de S. Paulo, Sao Paulo, 9 March 2003.

30. El Tiempo, Bogotá, 3 March 2006.

31. On this, see J. Rosenau, Along the Domestic-Foreign Frontier. Exploring Governance in a Turbulent World (Edinburgh, New York: Cambridge University Press 1997).

32. According to the Argentinian press, a US State Department file underlines the traffic of women and children in MERCOSUR borders. See Clarín, Buenos Aires, 1 June 2005.

33. J. S. Nye, Jr., "What New World Order", Foreign Affairs 71/2 (1992).

34. J. Hill, Commander of the US Southern Command, North-South Center, "Building Regional Security Cooperation in the Western Hemisphere" (Washington, DC: US Department of State, Office of International Information Programs, 3 March 2003), available at <http://usinfo.state.gov>.

35. See posture statement of General B. Craddock, US Army Commander, US Southern Command, before the 109th Congress, Senate Armed Services Committee (15 March 2005), available at <http://www.senate.gov/armed_services/statement/2005>.

36. Clarín, Buenos Aires, 12 May 2006.

37. Remarks of A. Lake, assistant to the president for National Security Affairs, are essential to understanding the notion of "enlargement". See "From Containment to Enlargement", John Hopkins University School of Advanced International Studies, Washington, DC, Sept. 21, 1993; and "Defining Missions, Setting Deadlines", Defense Issues 11/14 (1996).

38. D. W. Ellwood, Rebuilding Europe: Western Europe, America and Postwar Reconstruction (London: Longman 1992).

39. The insulation of Latin America from the global international system is rooted in the decision of the United Kingdom to interpose its fleet to prevent the reconquest of Latin America by continental European powers.

40. J. Tulchin, "Oportunidades para América Latina. Un nuevo regimen de seguridad hemisférica", SER en el 20007 (March 1995) p. 28.

41. See W. Clinton, "Remarks at the American University Centennial Celebration", Feb. 26, 1993; US National Security Council, "A National Security Strategy for a New Century" (Washington, DC: White House, Dec. 1999).

42. R. F. Perl, "United States Andean Drug Policy: Background and Issues for Decisionmakers", Journal of Interamerican Studies and World Affairs 34/3 (Autumn 1992) pp. 13-36.

43. G. C. Smith, "The Andean Trade Preference Act", Denver Journal of International Law \& Policy 21/1 (1992) pp. 149-58.

44. See I. F. Gellman, Good Neighbor Diplomacy. United States Policies in Latin America, 1933-1945 (Baltimore, The Johns Hopkins University Press 1979).

45. Tulchin (note 40) p. 29. 
46. Clarín, Buenos Aires, 15 June 2005 and ABC, Asunción, 29 June 2005.

47. The dependence on foreign oil and instability in the Middle East led to a push to diversify the sources of energy. See "National Energy Policy Report" (May 2001), available at $<$ http://www.whitehouse. gov/energy>. Venezuela and Colombia are important oil suppliers of the United States. In the case of Colombia, oil companies have had an important role in the militarisation of the Plan. Colombian military battalions are assigned to defend the oil companies, a task that is shared with private military personnel.

48. Clarín, Buenos Aires, 8 Dec. 2004.

49. R. MacNamara, Sécurité américaine et paix mondiale (Paris: Fayard 1969).

50. This position would be taken up again in different ways. In 2005, C. Rice criticised Latin American

populists, comparing Chavez to Perón. La Nación, Buenos Aires, 13 May 2005.

51. Declarations of General J. Hill, Chief of US Southern Command, to the Committee on Armed Services of the US House of Representatives, on 24 March 2004, about hemispherical security. La Jornada, México DF, 29 March 2004.

52. La Nación, Buenos Aires, 28 Aug. 1999.

53. El Diario, La Paz, 22 April 2003.

54. Terrorism as a threat was present in Latin America even before 9/11. Until then, terrorism was focused, for the United States, in the Andean area. In 1999, within the framework of the OAS, the Inter-American Committee on Combat against Terrorism was created. In the First Plenary Session of the OAS after 9/11, which took place in Barbados in June 2002, the InterAmerican Convention against Terrorism defined "terrorism". Terrorism as a subject matter was present in the different Hemispherical Summits.

55. Criminal organisations can be described as polymorphous phenomena based on highly organised and hierarchical structures that involve the systematic practices of violence and illegality with the aim of accumulating wealth, power and influence.

56. During his visit to Latin America in 1999, B. McCaffrey asked MERCOSUR to pressure Paraguay to stop tolerating drug trafficking.

57. See «Conclusiones Generales de la Misión Internacional de Observación », CADA, Paraguay, 15-20 July 2006.

58. Clarín, Buenos Aires, 15 June 2005.

59. The Triple Frontera consists of three cities: Foz do Iguaçu (Brazil), Puerto Iguazú (Argentina) and Ciudad del Este (Paraguay). The main economic activity of Foz do Iguaçu and Puerto Iguazú is tourism, while in Ciudad del Este the trade of smuggled goods predominates. This region is a traditional place of intense clandestine activities, where all kinds of global disorder (illicit traffic of weapons, drugs, stolen cars, human beings and animals, fake identity documents, false products, etc.) can be observed. In Brazil and Paraguay, migrant colonies from the Middle East (especially Syria and Lebanon) have existed for a long time and increased with the arrival of Lebanese Shiites after the civil war in Lebanon. Since 2002, the Triple Frontera concept has been used to describe other places, such as the area between Bolivia, Paraguay and Brazil and between Brazil, Argentina and Uruguay. 60. Clarín, Buenos Aires, 15 March 2000.

61. O Globo, Sao Paulo, 28 Oct. 2001.

62. Hill (note 34).

63. According to the United States, al-Qaeda was preparing attacks against the American embassies in Ecuador and Uruguay. Clarín, Buenos Aires, 30 Oct. 2001.

64. ABC, Asunción, 13 August 2005.

65. On this topic, see the documents of the first and the second Foro Social de la Triple Frontera. Puerto Iguazú, Argentina, June 2004 and Ciudad del Este, Paraguay, July 2006, respectively. 
66. See G. B. Helman and S. R. Ratner, "Saving Failed States", Foreign Policy 89 (Winter 1993) pp. 3-21; R. Rotberg, "Failed States in a World of Terror", Foreign Affairs (July/Aug. 2002) p. 127.

67. The president of Chile, R. Lagos, proposed a mission of peace to intervene in Colombia.

68. O Estado de Sao Paulo, Sao Paulo, 8 March 2003.

69. According to a report presented to the US Congress, the attacks against the Cano LimónCovenas pipeline were reduced $60 \%$ thanks to US military aid. El Tiempo, Bogotá, 8 Oct. 2005.

70. Clarín, Buenos Aires, 7 June 2005.

71. Página 12, Buenos Aires, 12 May 2006.

72. See E. Manero, «Entre la fijación originaria y el eterno retorno: La Argentina y el Brasil frente a la estrategia americana para la region", in A. Fernández \& S. Gaveglio (eds.), Globalización, integración, Mercosur y desarrollo local (Rosario: Homo Sapiens 2000) pp. 77-90.

73. On this topic, see Joxe (note 3). 